UDC 378.046+378.09

\author{
Oksana V. Ivanova \\ National University of Life and Environmental Sciences of Ukraine, Kyiv, Ukraine \\ ORCID ID 0000-0003-1439-7996 \\ ivanoksi17@gmail.com
}

$\mathrm{PhD}$ (Pedagogy), associate professor of the Department of English for Technical and Agrobiological Specialities

\title{
THE USE OF E-PORTFOLIO TO DEVELOP ENGLISH LANGUAGE LEARNERS' AUTONOMY AND INDEPENDENCE
}

\begin{abstract}
This paper discusses the findings of a research study concerning the use of e-portfolios to develop learners' autonomy and independence, from the perspectives of teachers and students participating in this study. The findings demonstrate many of the benefits of e-portfolio practice regarding learners' increased sense of ownership, teacher and peer feedback, enriched learning experience at both individual and technological levels, enhanced opportunity for self-improvement and increased awareness of the learning process. Despite many positive aspects of e-portfolios use, the study reveals some challenges facing students, teachers and support staff, mainly connected with technical problems and Internet access, and the necessity for teachers and learners to change their roles to become more independent in the learning process. The author concludes that eportfolio is a promising tool to stimulate and challenge students to become independent and selfregulated learners that should be implemented in English language learning at higher educational institutions.
\end{abstract}

Keywords: English language learning: e-portfolio; independent learning; learning autonomy; metacognition.

\section{INTRODUCTION}

The problem setting. As we move forward through the information age, the implementation of information and communication technologies into education has become an imperative. During the first decade of the 21 st century, there has been increasing interest in the potential of an electronic portfolio (EP) to support more learner-centered and personalized forms of learning. An electronic portfolio is designed to engage students in metacognitive activities as it creates a framework to teach thinking and to promote self-directed learning. Implementing an electronic portfolio in education influences students' motivation, autonomy, goal-setting, performance, and reflection. An electronic portfolio as a digital container for storing visual and auditory content is also utilized to support a variety of pedagogical processes including reflecting on one's own learning and providing feedback to peers to stimulate their own reflections [1], 13]. These reflection processes are a key element in students' learning and effective communication between students. EPs have three broad purposes: process, presentation, and assessment, and often serve multiple purposes. According to Wade, Abrami\&Sclater, EPs are linked to students' ability to self-regulate and to enhance their meaningful learning of important educational skills and abilities [13]. Successful learners use self-regulation to effectively and efficiently accomplish a task, they aremetacognitively, motivationally, and behaviourally active participants in their own learning [15]. Broadly speaking, self-regulationis a complex process referred to learning that is guided by metacognition. Metacognition is the instrument that controls cognitive, motivational and contextual elements. Bransford, Brown \& Cocking call metacognition "an internal conversation" in which students monitor their own understanding and state that teachers should explicitly emphasize metacognition because it "can enhance student achievement and develop in students the ability to learn independently" [2, p. 18-21]. To develop effective self-regulated learning strategies, "students need to be involved in complex 
meaningful tasks, choosing the products and processes that will be evaluated, modifying tasks and assessment criteria to attain an optimal challenge, obtaining support from peers, and evaluating their own work" [9, p.716]. Miller \& Morgaine claim that e-portfolios make students think about their progress in learning and provide rich opportunities for metacognition through periodic reflections. They may help students develop an array of outcomes and skills such as:

- build learners' personal and academic identities as they complete complex projects and reflect on their capabilities and progress,

- facilitate the integration of learning as students connect learning across courses and time,

- be focused on developing self-assessment abilities in which students judge the quality of work using the same criteria experts use,

- help students plan their own academic pathways as they come to understand what they know and are able to do and what they still need to learn[11].

E-portfolios, therefore, allow students to think critically and to be more responsible for their learning, tobetter understand their strengths and limitations, to learn to set goals, and become active, independent and self-regulated learners.

Analysis of recent studies and publications. Many researchers and educators have recognized the potentials and benefits of electronic portfolios in learning. As MariiaUmryk suggests, today's students differ from students of previous years, that is why "understanding differences between the generations is fundamental in constructing of successful learningteaching process" [18, p.102]. I this regard Rhodes says that "portfolios might be the biggest thing in technology innovation on campus. Electronic portfolios have a greater potential to alter higher education at its very core than any other technology application we've known thus far" [10, p. 7]. The learning process can benefit from e-portfolios because they can make students work digitally and in an organized, searchable, and transportable way. According to Goldsmith, e-portfolios can foster the learning process since they allow teachers to understand "how well they are educating their students" and students, on their side, are able to assess "their educational experiences and achievements, and how these are linked to their personal goals" [4, p. 31]. As a personal development planning tool, EP helps students to plan, integrate and take responsibility for their personal, career and academic development; be more aware of how they learn; be more effective in monitoring and reviewing their own progress; develop their identity in relation to their academic, professional and personal progression. L. Gray suggests that "e-Portfolio use can provide opportunities to personalize even the most prescribed curriculum - creating e-portfolios enables learners to make their mark on the process of learning, but their approaches and needs will vary considerably" [8].

In the past decades, the technology of portfolio has received increased attention as an effective approach to providing learner-centered assessment in teaching foreign languages [19], [20], [21], [22], [23], [24]. There are numerous ways in which the portfolio can support teaching and learning processes that is why this technology is well recognized internationally, by all the members of the European Council, the United States, Canada, Ukraine and other countries. For one, TetianaPolonska examines the effectiveness of using the Ukrainian variant of the European Language Portfolio and makes it evident that this tool allows to conduct an ongoing evaluation of the learning process, promotes learning autonomy and motivation [22]. Oksana Karpiuk suggests that portfolios help to guide the learner in planning and assessing their progress and empower the learner by transferring the responsibility for language learning from the teacher to the learner [23, p. 213].

Some empirical studies compare e-portfolios with paper-based portfolios in order to obtain valid findings of the impact of using e-portfolios in language learning. It has been found that e-portfolios are easier to store, access, manage, and present. In addition, they 
permit organizing content and adding hyperlinks, videos, and audios in any time [3], [5], 12]. Chau and Cheng conducted a qualitative study on an e-portfolios competition to investigate the use of e-portfolios for enhancing independent learning and the challenges associated with them. Although the study showed some barrier of design and implementation, many benefits had emerged. First, a sense of ownership was increased among learners; second, using eportfolios supported independent learning through commitment, purpose, and strategies; and third, using e-portfolios made students control their learning goals and personal planning [16].

In language learning, an e-portfolio "may be a natural extension of [students'] demonstration of capable communication in a second language (English)" [17, p. 21]. Eportfolio allows language students to demonstrate their proficiency in a more dynamic format, show their teachers specific samples of their writing, listen to demonstrations of their speech, read reflections on their own performance, and see examples of their involvement in the target culture through photographs and video [17, p. 21].

To conclude this part, using e-portfolios can foster social interaction, meaningful context, motivation and self-esteem, and interpersonal support [6], [7]. Thus, changes in the learning environment expand and enrich classroom practices and influence students' view of integrating learning and technology.

The purpose of this article. In line with the ongoing developments at the National University of Life and Environmental Sciences of Ukraine, Kyiv, aimed at the adoption of innovative technology-assisted methods of teaching in order to enhance diverse dimensions of learning, this study attempts to assess the potential and identify the challenges of electronic portfolios as a powerful tool to promote learners' autonomy and independence. Our attention is focused on the particular aspects of independent learning rather than language improvement. Specifically, the article addresses the following issues:

1. What aspects are the most significant for understanding e-portfolio-assisted independent learning from the perspective of university students and teachers?

2. What are the challenges of encouraging more independent learning through eportfolios at university?

\section{METHODS OF THE STUDY}

In this research we use both theoretical and empirical methods. We employ literature review method to study and interpret the available research papers on the topic, to identify the nature of the basic concept of our study and obtain the actual information about e-portfolio sand their impact on learners' autonomy. As for the research procedure, a group of university students was engaged in the study at the National University of Life and Environmental Sciences of Ukraine in Kyiv. The research was carried out with the group of 54 students (24 boys and 30 girls), their ages ranged from 19 to 21 years. They came from the Faculty of the Humanities and Pedagogy. An e-portfolio was developed and integrated into three English language courses (the average number of students - 18 in each course) during the 2016-17 academic year. Students were to utilize the e-portfolio to chronicle and demonstrate their learning advancement and accomplishments in English, as well as the ability to work independently, to their peers and teachers. Furthermore, we invited six experienced English language teachers to provide encouragement, advise students on language issues and offer assistance on independent language learning.

\section{THE FINDINGS OF THE STUDY}

Learner's autonomy is described as "willing, proactive and reflective involvement in one's own learning" [18], [20]. It is especially important in the foreign language classroom as learner's autonomy allows developing students' proficiency in the target language by 
involving them from the very beginning in spontaneous and authentic use of the language. To better understand the impact of e-portfolios use on students' learning autonomy, we need to clarify the concept of independent learning, which is a term frequently used in higher education.

Independent learning is understood as the way students manage their own learning. The key ingredient in independent learning is the shift of responsibility from the teacher to the student; teachers have a key part to play in assisting and supporting independent learning though. The process typically involves the following three phases [14]:

- Planning: self-identified goals and choice of artefacts using technological skills appropriate to the task

- Monitoring: review of individual progress towards one's goals from a dual perspective of learning being a product and a process, aided by teacher feedback

- Reflecting: modification of goals and/or deployment of repair strategies for further improvement

A significant part of independent learning is positive relationships between teachers, students and peers, based on trust. In successful independent learning the role of the teacher shifts from transmitting knowledge to helping students to acquire the strategies necessary for learning through scaffolding, offering models of behaviour, providing feedback, encouraging students to self-monitor, etc.

In our study, qualitative research method and post-event interviews with both students and teachers as a way of generating data, complemented by artefacts in students' e-portfolios and reflective entries were utilized. Post-event interviews consisted of two questionnaires designed both for participating teachers (A) and students (B). We also employed some elements of quantitative analysis to develop precise, objective and generalizable findings.

Table 1

Questionnaires for participating teachers and students

\begin{tabular}{|c|l|c|l|}
\hline \multicolumn{2}{|c|}{ Questionnaire A } & \multicolumn{2}{|c|}{ Questionnaire B } \\
\hline 1. & $\begin{array}{l}\text { Could you describe your experience in } \\
\text { using the e-portfolio - the good and the } \\
\text { bad? }\end{array}$ & 1. & $\begin{array}{l}\text { Could you describe your experience in } \\
\text { using the e-portfolio - the good and the } \\
\text { bad? }\end{array}$ \\
\hline 2. & $\begin{array}{l}\text { Do you feel that students achieved their } \\
\text { goal(s)? }\end{array}$ & 2. & $\begin{array}{l}\text { Do you feel that you achieved your } \\
\text { goal(s)? }\end{array}$ \\
\hline 3. & $\begin{array}{l}\text { About the e-portfolio for language } \\
\text { learning, could you name any aspects of } \\
\text { the e-portfolio you find most/ least } \\
\text { useful? }\end{array}$ & 3. & $\begin{array}{l}\text { About the e-portfolio for language } \\
\text { learning, could you name any aspects of } \\
\text { the e-portfolio you find most/ least } \\
\text { useful? }\end{array}$ \\
\hline 4. & $\begin{array}{l}\text { What are were the main challenges of } \\
\text { using the e-portfolio as an independent } \\
\text { language learning tool? }\end{array}$ & 4. & $\begin{array}{l}\text { What were the main challenges of using } \\
\text { the e-portfolio as an independent } \\
\text { language learning tool? }\end{array}$ \\
\hline 5. & $\begin{array}{l}\text { Did you give feedback on students' e- } \\
\text { portfolio showcases? }\end{array}$ & 5. & $\begin{array}{l}\text { Did you give feedback on peers e- } \\
\text { portfolio showcases? }\end{array}$ \\
\hline 6. & $\begin{array}{l}\text { Have you had any experience of helping } \\
\text { students with independent language } \\
\text { learning? }\end{array}$ & 6. & $\begin{array}{l}\text { Have you had any previous experience } \\
\text { in using an e-portfolio? }\end{array}$ \\
\hline 7. & $\begin{array}{l}\text { Do you have any suggestions / } \\
\text { comments for the e-portfolio? }\end{array}$ & 7. & $\begin{array}{l}\text { Do you have any suggestions / } \\
\text { comments for the e-portfolio? }\end{array}$ \\
\hline
\end{tabular}


The data obtained from the post-event interviews are presented in Tables 2-7 which demonstrate the number and percentage of the participants in regard to the particular questions of the questionnaire.

Table 2

Perceptions of the e-portfolio use

\begin{tabular}{|c|c|c|c|c|c|c|}
\hline \multirow{2}{*}{ Perceptions of the e-portfolio use } & \multicolumn{2}{|c|}{ Positive } & \multicolumn{2}{c|}{ Neutral } & \multicolumn{2}{c|}{ Negative } \\
\cline { 2 - 7 } & Number & $\%$ & Number & $\%$ & Number & $\%$ \\
\hline Students & 32 & 59 & 16 & 30 & 6 & 11 \\
\hline Teachers & 5 & 83 & 1 & 17 & - & - \\
\hline
\end{tabular}

Goal (s) achievement

Table 3

\begin{tabular}{|c|c|c|c|c|c|c|}
\hline \multirow{2}{*}{ Goal (s) achievement } & \multicolumn{2}{|c|}{ Achieved } & \multicolumn{2}{c|}{ Partly achieved } & \multicolumn{2}{c|}{ Not achieved } \\
\cline { 2 - 7 } & Number & $\mathbf{\%}$ & Number & $\%$ & Number & $\%$ \\
\hline Students & 29 & 54 & 24 & 44 & 1 & 2 \\
\hline Teachers & 4 & 67 & 1 & 16,5 & 1 & 16,5 \\
\hline
\end{tabular}

Table 4

The most useful aspects of the e-portfolio

\begin{tabular}{|c|l|c|c|c|c|}
\hline \multicolumn{2}{|c|}{$\begin{array}{c}\text { The most useful aspects } \\
\text { of the e-portfolio }\end{array}$} & \multicolumn{2}{c|}{ Students } & \multicolumn{2}{c|}{ Teachers } \\
\cline { 2 - 5 } & Number & Number & 67 \\
\hline 1. & $\begin{array}{l}\text { The ability to include } \\
\text { digital content }\end{array}$ & 48 & 89 & 4 & 83 \\
\hline $\begin{array}{l}\text { The ability to work } \\
\text { independently and at an } \\
\text { individual pace }\end{array}$ & 24 & 44 & 5 & 33 \\
\hline 3. & Ease of storage & 18 & 33 & 2 & 67 \\
\hline 4. & $\begin{array}{l}\text { Granting general access to peers and } \\
\text { teachers }\end{array}$ & 37 & 68 & 4 & 83 \\
\hline 5. & $\begin{array}{l}\text { The ability to reflect on what has been } \\
\text { learnt or achieved }\end{array}$ & 28 & 52 & 5 & 50 \\
\hline 6. & Awareness of the learning process & 41 & 76 & 3 & \\
\hline
\end{tabular}

Table 5

The main challenges of using the e-portfolio

\begin{tabular}{|c|l|c|c|c|c|}
\hline \multicolumn{2}{|c|}{ The main challenges of using the e- } & \multicolumn{2}{c|}{ Students } & \multicolumn{2}{c|}{ Teachers } \\
\cline { 3 - 5 } portfolio & Number & \% & Number & \% \\
\hline 1. & $\begin{array}{l}\text { The Internet connection and technology } \\
\text { glitches }\end{array}$ & 8 & 15 & 2 & 33 \\
\hline $\begin{array}{l}\text { Lack of technological competence } \\
\text { (video editing, audio editing, digital } \\
\text { photography, etc.) }\end{array}$ & 12 & 22 & - & - \\
\hline 3. & Time-consuming technology & 25 & 46 & 4 & 67 \\
\hline 4. & Lack of computers in the classroom & 19 & 35 & 6 & 100 \\
\hline
\end{tabular}


Table 6

Providing feedback on students'/peers' e-portfolio showcases

\begin{tabular}{|c|c|c|c|c|c|c|}
\hline \multirow{2}{*}{$\begin{array}{c}\text { Did you give feedback on } \\
\text { students'/peers' e-portfolio } \\
\text { showcases? }\end{array}$} & \multicolumn{2}{|c|}{ Yes } & \multicolumn{2}{c|}{ Not regularly } & \multicolumn{2}{c|}{ No } \\
\cline { 2 - 7 } & Number & $\%$ & Number & $\%$ & Number & $\%$ \\
\hline Students & 23 & 42 & 15 & 28 & 16 & 30 \\
\hline Teachers & 6 & 100 & - & - & - & - \\
\hline
\end{tabular}

Table 7

Previous experience of using e-portfolio

\begin{tabular}{|c|c|c|c|c|c|c|}
\hline \multirow{2}{*}{$\begin{array}{c}\text { Previous experience of using e- } \\
\text { portfolio }\end{array}$} & \multicolumn{2}{|c|}{$\begin{array}{c}\text { Yes, } \\
\text { at college or school }\end{array}$} & \multicolumn{3}{c|}{ No } \\
\cline { 2 - 8 } & Number university & \% & Number & $\%$ & Number & $\%$ \\
\hline Students & 13 & 24 & 18 & 34 & 23 & 42 \\
\hline Teachers & - & - & 6 & 100 & - & - \\
\hline
\end{tabular}

Overall, participants' perceptions of use of the e-portfolio were positive. Most teachers $(85 \%)$ and $59 \%$ students reported that they had been feeling positive while working with the e-portfolios. Nevertheless, $11 \%$ students reported negative perception which could be explained by problems with the Internet connection and lack of technological competence (see Table 5). Also 46\% students and 67\% teachers indicated that e-portfolio is a timeconsuming technology which might have influenced their perception of the current eportfolios. Moreover, both students (35\%) and teachers (100\%) were not satisfied with the classroom arrangements and equipment (lack of computers). Most respondents achieved or partly achieved their learning goals, only $2 \%$ students and $16,5 \%$ teachers felt that they failed to achieve their goals (see Table 3). Students also indicated that the e-portfolio allowed them to include digital content $(89 \%)$, to work independently and at an individual pace $(44 \%)$, to reflect on their achievements (52\%) as well. Ease of storage, granting general access to peers and teachers, awareness of the learning process were also indicated as the most useful aspects in using the e-portfolios by both teachers and students. These aspects are especially beneficial in learning foreign languages as they give learners the opportunity to develop and improve their listening, writing and reading skills. For example, while listening to digital audio or watching a video clip, learners have the opportunity to pause and listen again which suggests good strategies for improving listening abilities. Moreover, giving peer feedback creates multiple opportunities for authentic communication and helps learners to train their writing skills in the enxiety-free context. Although many students found the feedbacks they received to be encouraging and useful (which builds their confidence and motivation), 30\% students avoided giving peer feedback (see Table 6). This fact could be explained by lack of previous experience in using e-portfolio, as shown in Table $7(42 \%$ students had no previous experience). But the most beneficial thing here, in our opinion, that students could work independently and at their own pace, plan and control their learning process, which better caters to their individual learning needs and develop English language learners autonomy.

Through analyzing teachers' and students' responses, five major aspects emerged as significant for understanding e-portfolio-assisted independent learning: 1) choice and ownership; 2) feedback; 3) technological competence; 4) self-improvement and strategies; and 5) Reflection.

\section{Aspect 1. Choice and ownership}

The e-portfolio comprised templates and guidelines for evidence selection and selfreflection, however, students felt flexible to identify their own goals and include artifacts of 
their choice in their portfolios which enabled creativity and ownership. The opportunity to complete a self-initiated task in their own way was seen as an advantage from both students' and teachers' perspective.

Student perspectives: "I can present my own materials, like audios, videos, documents ... there is no restriction and I can be creative in what I present..."

Teacher perspectives:"The e-portfolio gives students an extra opportunity to learn language in the way that relates to their own learning style."

So, both teacher and students find "Choice and ownership" aspect to be very important and advantageous in e-portfolio-assisted independent learning.

\section{Aspect 2. Feedback}

Although students were encouraged to reflect on their peers performance, they tended to assign less importance to peer feedback, but consistently agreed on the usefulness of teacher comments for language learning. Teachers highlighted the importance of relevant and judgment-freepeer feedback in order for everyone to truly benefit from it.

Student perspectives: "I really appreciate my teacher's help and feedback on my work and progress..."

Teacher perspectives: "As for me, feedback gives the students an opportunity to have their voices heard; in this regard, peer feedback could be more beneficial as it comes from people of the same age and shared interests .... it is ... like a two-way relationship...you see a video, you read some comments, and respond..."

In this regard, the use of the e-portfolio has many positive implications for the English teachers and students. The students feel they are given the opportunity to improve on their work, and the teachers can see how quickly and to what extent they are improving.

\section{Aspect 3. Technological competence}

Technological competence was another aspect. Both students and teachers indicated that it was a challenge for them to learn to use the e-portfolio effectively for independent learning, however, some students mentioned that using e-portfolios in general was never a challenge for them. Most respondents referred their challenges to internet connection and technical problems while using the site.

Student perspectives:

"It's challenging for me as I lack proper computer skills."

"I don't think it [e-portfolio] is challenging to use."

Teacher perspectives: "I'm not particularly good at navigating throughout websites."

"If the internet is slow, it is hard to access..."

So, technological competence is regarded as one of the aspects that can cause problems to both students and teachers. Nevertheless, the number of computer literate students and teachers exceeds those with lack of technological competence. Most of modern students greatly appreciate the use of e-portfolios because it allows them to easily demonstrate their development and overall strengths in using English.

\section{Aspect 4: Self-improvement and strategies}

As student comments showed, using e-portfolio supports independent learning and enables students to control their learning goals and personal planning. Some teachers pointed out that e-portfolio use allows students to become more independent learners and consider their strengths and weaknesses, to improve their self-development, learning process, and selfreflection.

Student perspectives: "Using the e-portfolio system can help me to think more ... and improve my learning process."

Teacher perspectives: "Every student has a different way of learning ... e-portfolio enhances motivation in language learning and encourages students to develop their autonomy." 
Thus, e-portfolio allows learners to take more responsibility for documenting and assessing their language abilities and plan their own academic pathways according to their individual learning style and pace of learning.

\section{Aspect 5: Reflection}

Our findings on e-portfolio practice confirmed awareness of the need for selfimprovement and self-reflection which can help to understand what strategies worked and what strategies did not work and improve learning according to those findings. In addition, reflection enables students to monitor the development in their learning.

Student perspectives: English."

"It helps me to reflect on my own work and know what I need to do more to improve my idea..."

"It really helps me to see my own personal growth ... I think reflection is really a good

Teacher perspectives: "It gives students an opportunity to set and develop their goals and experience deeper levels of learning through self-development, self-reflection and selfenrichment."

Reflection, therefore, is shown as a powerful aspect by both teachers and students as it allows to comment and make suggestions for improvement; the students feel that the teacher genuinely cares about their progress, and the teacher feels that the students are active participants in their learning and development.

While noting the potential of e-portfolios as an independent learning tool, there also were challenges at the levels of students and teachers observed. Despite mainly positive perception of e-portfolios, some students and teachers faced technical problems as they used e-portfolios for the first time. Therefore, continual user support for both staff and students should not be underestimated particularly when the system is first introduced. Also, the participants had problems with the Internet connection and technology glitches. Another challenge is that the new learning environments require teachers and learners to change their roles and routines: from lecturing to listening, from coaching to participating and this is the pathway that leads to developing learners' autonomy and independence. According to our study, both teachers and students found it time-consuming and therefore difficult to fit eportfolio into their teaching/learning routine which did not encourage the active use of portfolios. Finally, teachers were frustrated that they were either restricted in the use of the computer lab, or had one to three computers in their classrooms that prevented them from using this technology on a regular basis.

\section{THE CONCLUSIONS AND PROSPECTS OF FURTHER RESEARCH}

The literature review indicates that e-portfolio technology can be used to develop students' self-regulated and independent learning. E-portfolio-based learning requires students to be active participants in the learning process as they are responsible for every step of it from selecting the content of e-portfolios, setting goals to reflecting and evaluating their learning process. It helps students plan their own learning process as they learn to understand what they have already known and what they still need to work on.

An analysis of students' and teachers' responses, together with e-portfolio evidence and reflection, demonstrate many of the benefits of e-portfolio practice particularly regarding learners' increased sense of ownership, relevant teacher and peer feedback, enriched learning experience at both individual and technological levels, enhanced opportunity for selfimprovement and increased awareness of the learning process. The findings of our study show that the use of e-portfolios is especially beneficial in learning foreign languages as it helps students to improve both their language and organizational skills, to assess their language 
abilities, to become more responsible, active and autonomous while studying. In addition, the positive effect is achieved through enhancing learners' motivation and promoting the anxietyfree use of the target language (English). For these reasons, e-portfolio is a promising tool to stimulate and challenge students to become independent and self regulated learners that should be implemented in higher education.

Despite many positive aspects of e-portfolios use, there are some challenges facing students, teachers and support staff, mainly connected with technical problems and internet access, and the necessity for teachers and learners to change their roles to become more independent in the learning process. As it has been shown in this research, many processes involved in electronic portfolio building could be novel to students and, therefore, methodological support is needed to help them commit to this time-consuming process. Thus, our study suggests that students and teachers should be better prepared technically and methodologically for the e-portfolio use, which in turn will maximize the learning potential of this technology.

There are still many problematic issues needed to be answered. One of them is "What are the long-term impact of e-portfolio practice on independent learning?" Searching for the answer to this question could be the focus of our further research. encouraging self evaluation and allowing learners to have a higher degree of control over the learning process

\section{REFERENCES (TRANSLATED AND TRANSLITERATED)}

[1] P.C. Abrami, H. Barrett, "Directions for research and development on electronic portfolios", Canadian Journal of Learning and Technology, no 31(3), pp. 1-15, 2005. (in English)

[2] J.D. Bransford et al. How people learn: Brain, mind, experience, and school. Washington, DC: National Academy Press, 2000. (in English)

[3] D. Cambridge. E-portfolios for lifelong learning and assessment. San Francisco, C.A.: Jossey-Bass, 2010. (in English)

[4] D.J. Goldsmith, "Enhancing learning and assessment through e-portfolios: A collaborative effort in Connecticut", New Directions for Student Services, no 119, pp. 31-42, 2006. (in English)

[5] H. Barrett, "Using electronic portfolios for classroom assessment", Connected Newsletter, 13(2), pp.4-6, 2006. (in English)

[6] D.M. Jacobsen, "Building different bridges two: A case study of transformative professional development for student learning with technology", In Validity and Value in Educational Research, the 83rd Annual Meeting of the American Educational Research Association, 2002. (in English)

[7] L.A. Levin, R. Wadmany, "Teachers' beliefs and practices in technology-based classrooms: A developmental view". Journal of Research on Technology in Education, no 39(2), pp. 159-180, 2006. (in English)

[8] L. Gray. "Effective Practice with e-Portfolios". [Online]. Available: http://www.ssphplus.info/files/effective_practice_e-portfolios.pdf (in English)

[9] N.E. Perry, "Young children's self-regulated learning and contexts that support it", Journal of Educational Psychology, no 90, pp. 715-729, 1998. (in English)

[10] T. L. Rhodes, "Making learning visible and meaningful through electronic portfolios", Change, pp. 6-132, 2011. (in English)

[11] R. Miller, W. Morgaine, "The Benefits of E-portfolios for Students and Faculty in Their Own Words". [Online]. Available: https://www.aacu.org/publications-research/periodicals/benefits-e-portfoliosstudents-and-faculty-their-own-words (in English)

[12] L. Stefani et al., The educational potential of e-portfolios: Supporting personal development and reflective learning. London: Routledge, 2007. (in English)

[13] A. Wade, P.C. Abrami, J. Sclater, "An electronic portfolio for learning", Canadian Journal of Learning and Technology, No 31(3), pp. 33-50, 2005. (in English)

[14] P.H. Winne, "Self-regulated learning viewed from models of information processing". In Self-regulated learning and academic achievement: Theoretical perspectives, 2001, pp. 153-189. (in English)

[15] B.J. Zimmerman, "Attaining self-regulation: A social cognitive perspective", InHandbook of SelfRegulation, 2000, pp. 13-39. (in English) 
[16] J. Chau \& G. Cheng, "Towards understanding the potential of e-portfolios for independent learning: A qualitative study", Australian Journal of Educational Technology, no 26(7), pp. 932-950, 2010. (in English)

[17] V. Grant, "To 'E' Or Not To 'E' Electronic Portfolios in the Adult ESL Classroom". [Online]. Available:https://www.hpu.edu/CHSS/English/TESOL/ProfessionalDevelopment/201080TWPfall10/Gra ntEportfolio.pdf (in English)

[18] M. Umryk, "Using Active E-Learning to Accommodate the Net Generation of Learners". [Online]. Available: learning_and_lifelong_learning.pdf (in English)

http://weinoe.us.edu.pl/sites/weinoe.us.edu.pl/files/media/e-

[19] D. Little, "The Common European Framework of Reference for Languages and the European Language Portfolio: Involving learners and their judgments in the assessment process", Language Testing, No 22, pp.321-336, 2005. (in English)

[20] D. Little, "Language learner autonomy: some fundamental considerations revisited", Innovation in Language Learning and Teaching, No 1.1, pp.14-29, 2007. (eng)

[21] B. Babenko, "Experience in using Portfolio", Director of the school, No. 4, pp. 7-15, 2008. (in Ukrainian)

[22] T. Polonska, "Language portfolio as an innovative component of teaching and learning complexes in a foreign language for senior schools". [Online]. Available: http://undip.org.ua/upload/iblock/700/2_62.pdf (in Ukrainian)

[23] O. Karpiuk, "The Ukrainian model of ELP has every chance to appear in the near future", English, No. 41, 425p, 2008. (in Ukrainian)

[24] I. Dychkivska, Innovative pedagogical technologies. K.: Academic edition, 2004. (in Ukrainian)

Text of the article was accepted by Editorial Team 25.05.2017

\title{
ВИКОРИСТАННЯ ЕЛЕКТРОННОГО ПОРТФОЛІО ДЛЯ РОЗВИТКУ НАВЧАЛЬНОЇ АВТОНОМІЇ І НЕЗАЛЕЖНОСТІ СТУДЕНТІВ У ПРОЦЕСІ ВИВЧЕННЯ АНГЛІЙСЬКОЇ МОВИ
}

\author{
Оксана Вікторівна Іванова \\ кандидат педагогічних наук, доцент кафедри англійської мови для технічних \\ та агробіологічних спеціальностей \\ Національний університет біоресурсів і природокористування України, Київ, Україна \\ ORCID ID 0000-0003-1439-7996 \\ ivanoksi17@gmail.com
}

\begin{abstract}
Анотація. У статті обговорюються результати дослідження, присвяченого використанню електронних портфелів для розвитку автономії і незалежності студентів, які вивчають мову, 3 точки зору викладачів і студентів, які беруть участь в цьому дослідженні. Отримані результати демонструють багато переваг практики електронного портфеля, пов'язаних 3 підвищеним почуттям власності студентів, зворотнім зв'язком 3 викладачами та однолітками, збагаченням навчального досвіду як на індивідуальному, так i на технологічному рівнях, розширенням можливостей для самовдосконалення та підвищенням обізнаності про процес навчання. Зважаючи на багато позитивних аспектів використання електронних портфелів, дослідження виявляє деякі проблеми, 3 якими зіштовхуються студенти, викладачі та технічний персонал. Автор доходить висновку, що електронний портфель - це перспективний інструмент, який стимулює i спонукає студентів до самостійності і саморегуляції, який повинен бути використаний у процесі вивчення англійської мови у ВНЗ.
\end{abstract}

Ключові слова: вивчення англійської мови; електронний портфель; незалежне навчання; навчальна автономія; метапізнання. 


\title{
ИСПОЛЬЗОВАНИЕ ЭЛЕКТРОННОГО ПОРТФОЛИО ДЛЯ РАЗВИТИЯ УЧЕБНОЙ АВТОНОМИИ И НЕЗАВИСИМОСТИ СТУДЕНТОВ В ПРОЦЕССЕ ИЗУЧЕНИЯ АНГЛИЙСКОГО ЯЗЫКА
}

\author{
Оксана Викторовна Иванова \\ кандидат педагогических наук, доцент кафедры английского языка для технических \\ и агробиологических специальностей \\ Национальный университет биоресурсов и природопользования Украины, Киев, Украина \\ ORCID ID 0000-0003-1439-7996 \\ ivanoksi17@gmail.com
}

\begin{abstract}
Аннотация. В статье обсуждаются результаты исследования, посвященного использованию электронных портфелей для развития автономии и независимости студентов, изучающих английский язык, с точки зрения преподавателей и студентов, участвующих в этом исследовании. Полученные результаты демонстрируют многие преимущества практики электронного портфеля, связанные с повышенным чувством собственности студентов, обратной связью с преподавателями и сверстниками, обогащением учебного опыта как на индивидуальном, так и на технологическом уровнях, расширением возможностей для самосовершенствования и повышением осведомленности о процессе обучения. Несмотря на многие положительные аспекты использования электронных портфелей, исследование выявляет некоторые проблемы, с которыми сталкиваются студенты, преподаватели и технический персонал. Автор приходит к выводу, что электронный портфель - это перспективный инструмент, который стимулирует и побуждает студентов к самостоятельности и саморегуляции, который должен быть использован в процессе изучения английского языка в вузе.
\end{abstract}

Ключевые слова: изучение английского языка; электронный портфель; независимое обучение; учебная автономия; метапознание.

\section{(cc) $\mathrm{EY}-\mathrm{NC}-\mathrm{SA}$}

This work is licensed under Creative Commons Attribution-NonCommercial-ShareAlike 4.0 International License. 